\title{
Diversity of fungi from shrimp ponds in Chachoengsao Province, Thailand
}

\author{
Rakseree, S. ${ }^{1}$, Suanjit, S. ${ }^{2}$, Jaritkhuan, S. ${ }^{3}$, Pilantanapak, A. ${ }^{2 *}$ \\ ${ }^{I}$ Biological Science Program, Faculty of Science, Burapha University, Chonburi 20131, Thailand \\ ${ }^{2}$ Department of Microbiology, Faculty of Science, Burapha University, Chonburi 20131, Thailand \\ ${ }^{3}$ Department of Aquatic Science, Faculty of Science, Burapha University, Chonburi 20131, Thailand
}

\begin{abstract}
A survey of the fungi in Thai shrimp ponds was conducted with purpose of determining the biodiversity of lignicolous fungi present. The seasonal colonization pattern by lignicolous fungi on wooden baits submerged in three shrimp ponds in Chachoengsao Province was determined over a 20-month period extending from April 2010 to January 2012. The wooden baits were deployed every 3 months and left submerged for a month before they were recovered and evaluated. The fungi were identified and isolated into axenic cultures. The total number of fungi recorded was 21 species. The highest numbers of fungal species found were 18 species from the April 2010 sample, which comprised 12 Ascomycota and 6 anamorphic fungi. Four fungi were commonly encountered (frequency $>30 \%$ ), namely Lulworthia grandispora, Haiyanga salina, Verruculina enalia and Periconia prolifica. One species of Massarina can be considered as "rare" (frequency $<1 \%$ ). Shannon-Wiener index $\left(H^{\prime}\right)$ for the fungi was determined to be in the range 1.37-2.18, whilst evenness $\left(J^{\prime}\right)$ value was close to $1(0.62-0.79)$ suggesting that the major fungal species that were found were regularly encountered and present in high abundance. The percentage of occurrence of fungal species was significantly positive correlated with water salinity and temperature.
\end{abstract}

Keywords : Diversity, Fungi, Shrimp pond, Thailand

\section{INTRODUCTION}

Shrimp pond is man-made ecosystem that requires salt water to feed the shrimp. Shrimp culture in Thailand is well established and has been practiced throughout the country for the last 90 years [1]. Intensive shrimp farming began principally in the upper Gulf of Thailand, South of Bangkok, in areas that previously had been devoted to extensive aquaculture. In 1989, farms within the region suffered heavy losses of shrimp from disease and unexplained mortalities. The focus for development then shifted to the provinces along the eastern coast of the country, i.e. Chachoengsao, Chanthaburi, Trat, Rayong and Chonburi. Of these, Chachoengsao is the largest in area measuring approximately 55.86 square kilometers [1].

Optimal salinity levels for the culture of shrimp are around 15-20 psu (1.5-2.0\%) [1]. Shrimp ponds in Thailand vary in salinity and range from 5-38 psu [2]. Shrimp ponds typically have high levels of organic waste, ammonia-nitrogen, and, organic matter which result from uneaten shrimp food, shrimp exuviate, plankton and dead algae in pond sediment [1]. The chemical and physical features within ponds are continually changing; as a result microorganisms within the pond are able to respond to the various stresses, making them excellent survivors [3].

Microorganisms living in extreme ecosystems usually produce secondary metabolites [4]. Interestingly, microorganisms recovered from certain marine ecosystems are an important source of enzymes that are used in a variety of industries including the waste disposal industry [5]. Within the biomedical sphere, there are problems of drug resistance and so there is a need to search for effective drug replacements. There is, therefore, concerted effort in conducting biodiversity surveys with the aim of identifying new microorganisms and new bioactive products. Fungi are also important as they may represent a source of novel bioactive substances and new chemical structural substances. Lignicolous fungi that are commonly found in estuarine waters with similar levels of salinity to those found in shrimp ponds, have been reported as important sources of bioactive compounds [6]. The diversity of fungi found in Thai shrimp ponds has not been studied and therefore it is unknown whether shrimp ponds represent important source of novel bioactive compounds.

The present study, was conducted to determine the biodiversity of fungi in a set of shrimp ponds in Chachoengsao Province of Thailand. The seasonal pattern of fungal colonization on pieces of wood bait deployed in ponds was investigated as a basis for further advanced study.

\section{MATERIALS AND METHODS}

\subsection{Study area}

The study site comprised three shrimp ponds located in Chachoengsao Province in the Eastern part of Thailand $\left(13^{\circ} 28^{\prime} \mathrm{N}, 100^{\circ} 54^{\prime} \mathrm{E}\right)$. All shrimp ponds were located next to a small area of mangrove (Fig. 1). The 
depth and surface area of each pond was $1.5 \mathrm{~m}$ and 1,600 $\mathrm{m}^{2}$, respectively. Each pond was operated as closed system without water renewal throughout the pond. Water for filling the ponds was pumped from a natural mangrove adjacent to the shrimp ponds. The culture conditions and pond management such as feed, water, aeration and shrimp density within each pond were similar (pers. comm. Mr. Somjit Yawong).

\subsection{Sampling strategies}

Fungal samples were collected from April 2010 to January 2012. Three stations within each shrimp ponds were randomly selected for the submersion of the wood baits. Prior to the experiment, a total of 9 nylon bags were sterilized by autoclaving at $121^{\circ} \mathrm{C}$ for $20 \mathrm{~min}$ and then they were dried at $50^{\circ} \mathrm{C}$ for 24 hours. Five pieces of mature mangrove wood, each measuring $1 \mathrm{~cm}$ in width and $2.5 \mathrm{~cm}$ in length, were placed into each bag to serve as fungal substrates. All bags were maintained in plastic baskets, attached to metal poles at each station and positioned $50 \mathrm{~cm}$ below the water's surface, for a period of one month. Thereafter, the bags were retrieved; the wood samples were cleaned and incubated at $25^{\circ} \mathrm{C}$ for one month before examining in the laboratory. The experimental design for baiting is presented in Table 1.
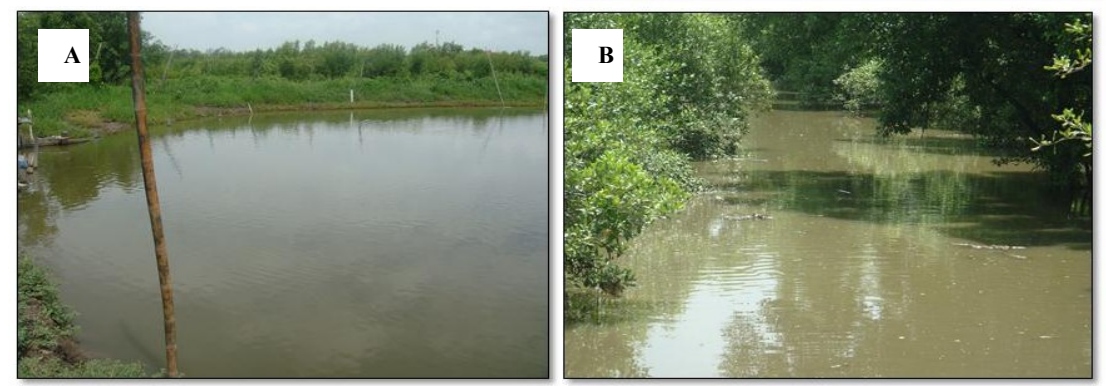

Fig. 1. Shrimp ponds in Chachoengsao province (A) and the mangrove region next to the sample ponds where water was pumped into the shrimp ponds (B).

Table 1. Experimental design for baiting experiment.

\begin{tabular}{lc}
\hline Study duration; no. of time points & 22 months; 8 (every 3 months) \\
No. of shrimp ponds selected for testing & 3 \\
Total no. of bait pieces submerged in each pond & 15 \\
Total number of bait samples analyzed each month & 45 \\
Size of each bait (diameter $\times$ length) & $1 \mathrm{~cm} \times 2.5 \mathrm{~cm}$ \\
Depth at which bait were submerged & $0.5 \mathrm{~m}$ \\
\hline Total no. of bait samples & 360 \\
\hline
\end{tabular}

\subsection{Chemical analysis of water samples}

Water samples were collected on the same day that the bags were removed from the shrimp ponds. Dissolved oxygen (DO) was estimated by azide modification of the iodometric method [7], whilst water temperature, salinity and $\mathrm{pH}$ were measured in the field using a multi parameter probe (YSI Model 556 MPS).

\subsection{Fungal identification}

The morphology of the fungi on the wood samples was determined using a dissecting microscope to screen for fruit bodies and spores. Thereafter, the identification of species was made following the dichotomous keys of Hyde and Pointing [8], Kohlmeyer and Kohlmeyer [9] and Barnett and Hunter [10]. Interesting fungi were photographed under microscope (Nikon E 600)

\subsection{Analysis of fungal diversity}

The percentage occurrence of fungi was determined by dividing the number of samples on which a particular fungal species occurred (multiplied by 100) by the number of samples that were examined. Simpson's species richness $\left(\mathrm{D}^{\prime}\right)$, Shannon-Wiener $\left(\mathrm{H}^{\prime}\right)$ and evenness $\left(\mathrm{J}^{\prime}\right)$ diversity indices were applied to the taxa and analyzed statistically [11]. In addition, a Pearson's correlation index was used to determine whether there were any correlations between the environmental parameters and the percentage of fungal occurrence.

\subsection{Sample analysis}

\section{RESULTS}

Water parameters are presented in Table 2. The salinity, temperature, $\mathrm{pH}$ and dissolved oxygen within the ponds ranged from $10-24 \mathrm{psu}, 28-31^{\circ} \mathrm{C}, 7.6-8.1$ and $1.13-5.67 \mathrm{mg} / \mathrm{L}$, respectively. Salinity was highest in January 2012 when it peaked at 24 psu and then in April of each year. The observed range in water temperature was quite narrow. 
Table 2. Water parameters within the shrimp ponds at number of sample time points throughout the study.

\begin{tabular}{lcccccccc}
\hline \multirow{2}{*}{ Parameters } & \multicolumn{7}{c}{ Months } \\
\cline { 2 - 7 } & Apr.2010 & Jul.2010 & Oct.2010 & Jan.2011 & Apr.2011 & Jul.2011 & Oct.2011 & Jan.2012 \\
\hline Salinity $(\mathrm{psu})$ & 20.00 & 16.00 & 17.00 & 10.00 & 21.00 & 11.00 & 18.00 & 24.00 \\
Temperature $\left({ }^{\circ} \mathrm{C}\right)$ & 31.00 & 29.00 & 30.00 & 28.00 & 30.00 & 28.00 & 31.00 & 31.00 \\
pH & 7.80 & 8.10 & 8.00 & 8.00 & 7.60 & 8.00 & 7.80 & 7.70 \\
DO $(\mathrm{mg} / \mathrm{L})$ & 4.63 & 5.67 & 5.43 & 1.47 & 4.80 & 1.13 & 2.73 & 4.93 \\
\hline
\end{tabular}

\subsection{Fungal biodiversity and seasonal variation}

A total of 21 lignicolous fungi, including 14 ascomycetes and 7 anamorphic taxa, were recorded from 360 wood samples that were deployed in this study. The occurrence and distribution of these fungal species are shown in Table 3. Among these, the highest number of fungal taxa was found on the samples collected in April 2010 when 18 species were recovered. The lowest number of species was found on the wood samples collected in January 2011 and July 2011. The most commonly occurring species were Periconia prolifica (98.9\%), Luworthia grandispora (71.9\%), Haiyanga salina (33.1\%) and Verruculina enalia (31.7\%). All the dominant species were found each month; the number of $P$. prolifica that were recovered did not appear to change from month to month. There was, however, some fluctuation in the occurrence of L. grandispora, H. salina and $V$. enalia throughout the study.

Table 3. Occurrence and distribution of fungi on the 360 wood bait samples collected from the shrimp ponds

\begin{tabular}{|c|c|c|c|c|c|c|c|c|c|c|}
\hline Fungal species & $\begin{array}{l}\text { Apr. } \\
2010\end{array}$ & $\begin{array}{c}\text { Jul. } \\
2010\end{array}$ & $\begin{array}{l}\text { Oct. } \\
2010\end{array}$ & $\begin{array}{c}\text { Jan. } \\
2011\end{array}$ & $\begin{array}{l}\text { Apr. } \\
2011\end{array}$ & $\begin{array}{c}\text { Jul. } \\
2011\end{array}$ & $\begin{array}{l}\text { Oct. } \\
2011\end{array}$ & $\begin{array}{c}\text { Jan. } \\
2012\end{array}$ & $\begin{array}{c}\text { Total } \\
\text { number of } \\
\text { occurrence }\end{array}$ & $\begin{array}{c}\text { Percentage } \\
\text { of } \\
\text { occurrence }\end{array}$ \\
\hline \multicolumn{11}{|l|}{ Ascomycetes } \\
\hline Luworthia grandispora & 42 & 40 & 39 & 29 & 21 & 30 & 21 & 37 & 259 & 71.9 \\
\hline Halospheia minuta & 6 & 2 & 1 & 1 & & & 1 & 1 & 12 & 3.3 \\
\hline Halospheia sp. & 1 & 3 & 1 & & & & & & 5 & 1.4 \\
\hline Leptosphaeria peruviana & & 1 & & & 2 & & & 1 & 4 & 1.1 \\
\hline Antennospora quadricornuta & 3 & 1 & & & 2 & & & 1 & 7 & 1.9 \\
\hline Haiyanga salina & 12 & 3 & 16 & 2 & 9 & 2 & 36 & 39 & 119 & 33.1 \\
\hline Marinosphaera mangrovei & 10 & 2 & & 4 & 6 & 3 & 18 & 24 & 67 & 18.6 \\
\hline Corollospora colossa & 1 & 2 & 1 & 1 & 1 & & & & 6 & 1.7 \\
\hline Corollospora bulbosa & 2 & & & & & & 2 & 6 & 10 & 2.8 \\
\hline Corollospora pulchella & 3 & & & & 2 & & 1 & 2 & 8 & 2.2 \\
\hline Aniptodera chesapeakensis & 6 & & & & 2 & & & 1 & 9 & 2.5 \\
\hline Torpidospora sp. & 2 & & 1 & & 1 & & 1 & & 5 & 1.4 \\
\hline Verruculina enalia & 12 & 6 & 10 & 8 & 8 & 2 & 30 & 38 & 114 & 31.7 \\
\hline Massarina sp. & & 2 & 1 & & & & & & 3 & 0.8 \\
\hline \multicolumn{11}{|l|}{ Anamorphic taxa } \\
\hline Clavatospora bulbosa & 3 & & & & 1 & & 1 & 1 & 6 & 1.7 \\
\hline Periconia prolifica & 45 & 45 & 45 & 45 & 45 & 45 & 41 & 45 & 356 & 98.9 \\
\hline Trichocladium allopallonella & 6 & 5 & 9 & 2 & 16 & 11 & 12 & 21 & 82 & 22.8 \\
\hline Zalerion varium & 1 & 6 & 11 & 1 & 3 & 6 & 9 & 8 & 45 & 12.5 \\
\hline Cumulospora sp. & 3 & 1 & & & 1 & 3 & & & 8 & 2.2 \\
\hline Monodictys pelagica & 1 & 2 & & & & & 9 & 2 & 14 & 3.9 \\
\hline Cirrenalia pygmea & & & & & 3 & 3 & 1 & 3 & 10 & 2.8 \\
\hline Total no. of occurrence & 159 & 121 & 135 & 93 & 123 & 105 & 183 & 230 & & \\
\hline Percentage of occurrence & 43.3 & 36.6 & 37.5 & 25.8 & 34.2 & 29.2 & 50.8 & 63.9 & & \\
\hline Total no. of species & 18 & 15 & 11 & 9 & 16 & 9 & 14 & 16 & & \\
\hline
\end{tabular}

According to Simpson's index, the highest value was found in April 2010 (3.35), followed by April 2011 (3.12), whilst the lowest values were found in January 2011 (1.76) and in July 2011 (1.72). In accordance with Shannon-Wiener's index, the greatest values occurred in April 2010 (2.18), October 2011 (2.09) and in April 2011 (2.06), whereas the lowest values were recorded in July 2011(1.58) and in January 2011 (1.37). Shannon's Evenness index $\left(\mathrm{J}^{\prime}\right)$ was found to range from 0.62-0.79 (Table 4). The evenness $\left(\mathrm{J}^{\prime}\right)$ value was close to 1 indicating that the major fungal species that were found were regularly encountered and present in high abundance. 
Table 4. The species richness, diversity and evenness of fungi found in the shrimp ponds across the study period April 2010 to January 2012.

\begin{tabular}{lcccc}
\hline Months & Species recovered & $\begin{array}{c}\text { Species richness } \\
\left(\mathrm{D}^{\prime}\right)\end{array}$ & $\begin{array}{c}\text { Diversity indices Shannon } \\
\left(\mathrm{H}^{\prime}\right)\end{array}$ & $\begin{array}{c}\text { Shannon's Evenness } \\
\left(\mathrm{J}^{\prime}\right)\end{array}$ \\
\hline Apr. 2010 & 18 & 3.35 & 2.18 & 0.75 \\
Jul. 2010 & 15 & 2.92 & 1.80 & 0.67 \\
Oct. 2010 & 11 & 2.04 & 1.74 & 0.72 \\
Jan. 2011 & 9 & 1.76 & 1.37 & 0.62 \\
Apr. 2011 & 16 & 3.12 & 2.06 & 0.74 \\
Jul. 2011 & 9 & 1.72 & 1.58 & 0.72 \\
Oct. 2011 & 14 & 2.50 & 2.09 & 0.79 \\
Jan. 2012 & 16 & 2.76 & 2.14 & 0.77 \\
\hline
\end{tabular}

The relationship between the frequency of occurrence of fungal species and environmental parameters are shown in Table 5. The total frequency of occurrence showed a significant positive correlation with salinity $(0.80 ; \mathrm{p}<0.05)$ and with temperature $(0.84 ; \mathrm{p}<0.01)$, whereas a negative correlation was presented with $\mathrm{pH}$. It was found that the frequency of occurrence of L. grandispora and $V$. enalia showed significant positive correlations with the level of salinity and temperature. In addition, L. grandispora also showed a statistically significant correlation with the level of dissolved oxygen $(0.812 ; \mathrm{p}<0.05)$. For $H$. salina, a significant correlation could be seen between its occurrence and the temperature of the pond water $(0.793 ; \mathrm{p}<0.05)$. Conversely, the relationship between $P$. prolifica and water salinity and temperature was found to be negative.

Table 5. Pearson's correlation coefficient $(\gamma)$ between the frequency of fungi and the environmental parameters determined in the shrimp ponds.

\begin{tabular}{|c|c|c|c|c|}
\hline & Salinity & Temperature & $\mathrm{pH}$ & $\mathrm{DO}$ \\
\hline Total frequency $(\%)$ & $0.801^{*}$ & $0.844 * *$ & -0.562 & 0.371 \\
\hline Periconia prolifica & -0.74 & -0.393 & 0.173 & 0.256 \\
\hline Luworthia grandispora & $0.820^{*}$ & $0.781^{*}$ & -0.527 & $0.812^{*}$ \\
\hline Verruculina enalia & $0.731^{*}$ & $0.723^{*}$ & -0.522 & 0.367 \\
\hline Haiyanga salina & 0.676 & $0.793^{*}$ & -0.534 & 0.225 \\
\hline
\end{tabular}

** Correlation is significant at the 0.01 level $(\mathrm{p}<0.01)$.

* Correlation is significant at the 0.05 level $(\mathrm{p}<0.05)$.

\section{DISCUSSION}

From this study, a total of 21 species of fungi were recovered from the 360 wood bait samples that were submerged in the shrimp ponds for a period of one month on each occasion. The fungi comprised 14 species of Ascomycota and 7 species of anamorphic fungi. The species with the high frequency of occurrence were P. prolifica $(98.9 \%)$, L. grandispora $(71.9 \%)$, H. salina $(33.1 \%)$, and, $V$. enalia $(31.7 \%)$. The high frequency of $P$. prolifica from this study are similar to those reported in marine fungi and fungi in estuary by Sundari et al. [11] working in Malaysia and Singapore who found P. prolifica to be the most commonly encountered species. Likewise, P. prolifica appeared in $10 \%$ of the 3,327 collections, and one of the 88 species of fungi that were found, along the coast of India [13]. In addition, the study of Nambiar et al. [14], working in a number of coastal water bodies of Tamil Nadu (India), also found P. prolifica to be the most commonly encountered species. There is also good support for the common occurrence of the other major fungal species reported here; the study of Jones and Abdel-Wahab [15], working on Bahamas Island reported $V$. enalia and L. grandispora as the most commonly occurring species. This finding is also supported by that of Alias [16], who reported that $V$. enalia was the most frequently encountered species in one particular mangrove ecosystem in Malaysia.

Periconia prolifica was found at all the test sites in this study. Hughes [17], stated that $P$. prolifica is mainly confined to tropical and subtropical waters, whilst Vrijmoed et al. [18] highlighted that $P$. prolifica is a euryhaline species with a broad temperature tolerance. There for, the finding from this investigation also supported by this literature.

In comparison with diversity indices, it is evident that diversity (i.e. 1.37-2.18) and evenness indices (i.e. 0.62-0.79) from this survey were less than the study on woody substrates of the west coast of India, which diversity and evenness indices were recorded between 3.497-4.572 and 0.747-0.914, respectively. This finding may be due to a number of differ factors, including the rich detritus that is found in mangrove sediments. Such a proper condition could promote the enhancement of fungal species found in natural areas [19],[20],[21]. Supplement with the restriction of this survey, the chemical and physical features within shrimp ponds are continually changing and could affect the occurrence of fungi that consequently caused diminishing in species diversity.

The results of this study showed that water temperature and salinity were the most important factors in dictating the frequency of occurrence of fungal species. Higher occurrences corresponded with higher values of 
both factors. This finding is in agreement with that of Alias and Jones [22], who reported that seawater temperature and salinity were the principal environmental factors affecting the colonization of Rhizophora apiculata. In addition to this, the studies of Sadaba [23] and Jones [24] both indicated marine fungi predominated during the dry season when salinity was high, which affected to the colonization of Acanthus ilicifoliusculms.

This study found that the occurrence of $L$. grandispora and $V$. enalia were significantly correlated $(\mathrm{p}<0.05)$ with water temperature and salinity. Alias et al. [25] working in a Malaysian mangrove, stated that $V$. enalia is found distributed in saline waters ranging from $10-35 \mathrm{psu}$, whilst $L$. grandispora dominates in waters of $18-20$ psu.

P. prolifica showed a non-significant, negative correlation with water temperature and salinity. This finding differed somewhat from that of Vrijmoed et al. [18] who working in Hong Kong, recorded that P. prolifica showed a significant, positive correlation with water temperature but a negative correlation with salinity. However, lacking of document to be explain this relation that can be cited for comparison.

Dissolved oxygen showed a significant positive relation $(\mathrm{p}<0.05)$ to the occurrence of L. grandispora. The only report suggesting an association between DO and marine fungi is that of Kohlmeyer [26], however, insufficient details are provided to permit a robust appraisal of this possible relationship.

In this study, no significance effect of $\mathrm{pH}$ on the distribution of fungi. This result was similar to the finding of Hughes [27] and Johnson [28], who concluded that there was no evidence, in their studies, to suggest that $\mathrm{pH}$ was a factor linked to the distribution pattern of fungi. Wood [29], however, suggested that a broad $\mathrm{pH}$ tolerance may be a general characteristic of marine fungi. Thus, it should be noted that $\mathrm{pH}$ does not appear to be an important factor in this current study.

To our knowledge, the current study represents the first to investigate the biodiversity and the frequency of occurrence of fungi in shrimp ponds. In the absence of other similar studies, it is suggested that more surveys are now needed, to document the distribution of fungi in other shrimp pond and also other aquaculture systems and whether the occurrence of certain fungal species can be correlated to local environmental parameters.

\section{CONCLUSION}

In summary, a total of 21 species of lignicolous fungi were recorded from the shrimp ponds during the study, with the four most commonly occurring species $P$. prolifica, L. grandispora, H. salina and $V$. enalia. The diversity indices within the shrimp ponds were lower than those ported in other natural waters. The frequency of fungal occurrence was found to be positively correlated to water temperature and salinity.

\section{Acknowledgements}

The authors would like to thank Faculty of Science, Burapha University for financial support of this study. We also express their gratitude to thank Dr. Andrew Shinn from the Institute of Aquaculture, University of Stirling, UK, Dr. Jarunan Pratoomyot from Institute of Marine Sciences, Burapha University, Thailand and Dr. Warucha Prajongsak from Phranakhon Rajabhat University, Thailand for their many valuable help included comments and proofreading the manuscript.

\section{REFERENCE}

[1] S. Tookwinas, Shrimp farm in Thailand: Present status and future direction for research. Australian Centre for International Agricultural Research Proceedings. 1993, 10-15.

[2] C. Limsuwan, and P. Chanratchakool, A closed recycle system for sustainable black tiger shrimp culture in freshwater areas. in: Paper presented at the Fifth Asian Fisheries Forum: International conference on Fisheries and food Security Beyond the year 2000, 1998 November 11-14. Chiang Mai, Thailand; 1998.

[3] Y. Avnimelech, and G. Ritvo, Shrimp and fish pond soils: Processes and management. Aquaculture, 220, 2003, 549-567.

[4] J.C. Frisvad, and R.A. Samson, Emericellavenezuelensis, a new species with stellate ascospores producing sterigmatocystin and aflatoxin B1. Systematic and Applied Microbiology, 27, 2004, 672-680.

[5] J.C. Frisvad, Halotolerant and halophilic fungi and their extrolite production, in Cunde-Cimerman, N. et al. (Eds.), Adaptation to Life at High Salt Concentrations in Archaea, Bacteria, and Eukarya (Netherlands: Springer, 2005) 425-439.

[6] A. Debbab, A.H. Aly, and W.H. Lin, Bioactive compounds from marine bacteria and fungi. Microbial Biotechnology, 3(5), 2010, 544-563.

[7] G.R. Barnett, and E. Hurwitz, The use of sodium azide in the Wrinkler method for determination of dissolved oxygen. Sewage Works Journal, 11, 1939, 781 .

[8] K.D. Hyde and S.B. Pointingr, Marine Mycology : A practical approach (Hong Kong, Fungal Diversity Press, 2000)

[9] J. Kohlmeyer, and V. Kohlmeyer, Illustrated key to the filamentous higher marine fungi. Botanica Marina, 34, 1991, 1-61.

[10] H.L. Barnett, and B.B. Hunter, Illustrate genera of imperfect fungi (New York, Macmillan Publishing Company, 2006).

[11] R. Sundari, S. Vikineswary, M. Yusoff, and E.B.G. Jones, Observations on tropical arenicolous marine fungi on driftwood fromMalaysia and Singapore. Botanica Marina, 39, 1996, 361-375.

[12] A.E. Magurran, Measuring Biological Diversity (UK, Blackwell Publishing, 2004).

[13] K. Prasannarai, and K.R. Sridhar, Diversity and abundance of higher marine fungi on woody substrates along the west coast of India. Current Science, 81(3), 2001, 304-311. 


\section{Diversity of fungi from shrimp ponds in Chachoengsao Province, Thailand}

[14] G.R. Nambiar, K. Raveendran, Z. Changxing, and C.A. Jaleel, A grimpse of lignicolous marine fungi occurring in coastal water bodies of Tamil Nadu (India). C.R. Biologies, 331, 2008. 475-480.

[15] E.B.G. Jones, and A.M. Abdel-Wahab, Marine fungi from Bahamas Island. Botanica Marina, 48, 2005, 356-364

[16] S.A. Alias, Ecological and taxonomic studies of lignicolous marine fungi in Malaysian mangroves. doctoral diss., University of Portsmouth, U.K., 1996.

[17] G.C. Hughes, Geographical distribution of the higher marine fungi. Veroff. Inst. Meeresforsch. Bremerh., Suppl. 5, $1974,419-441$.

[18] L.L.P. Vrijmoed, I.J. Hodgkiss, and L.B. Thrower, Factors affecting the distribution of lignicolous marine fungi in Hong Kong. Hydrobiologia, 87, 1982, 143-160.

[19] A.I. Robertson, D.M. Alongi, and K.G. Boto, Food chains and carbon fluxes, in A.I. Robertson, and D.M. Alongi (Eds.), Tropical mangrove ecosystems. (Washington: American Geophysical Union, 1992) 293-329.

[20] G.L. Maria, K.R. Sridhar, and F. Barlocher, Decomposition of dead twings of Avicennia officinalis and Rhizophora mucronata in a mangrove in south western India. Botanica Marina, 49, 2006, 450-455.

[21] R.G. Nambiar, and K. Raveendran, Manglicolous marine fungi of Kerala (South India). Botany Research International, 2, 2009, 206-210.

[22] S.A. Alias and E. B. G. Jones, Colonization of mangrove wood by marine fungi at Kuala Selangor mangrove stand, Malaysia, Fungal Diversity, 5, 2000, 9-21.

[23] R.B. Sadaba, An ecological study of fungi associated with the mangrove associate Acanthus ilicifolius in Mai Po, Hong Kong. doctoral diss., University of Hong Kong, Hong Kong, 1996.

[24] E.B.G. Jones, Marine fungi: Some factors influencing biodiversity. Fungal Diversity, 4, 2000. 53-73.

[25] S.A. Alias, A.J. Kuthubutheen, and E.B.G. Jones, Frequency of occurrence of fungi on wood in Malaysian mangrove. Hydrobiologia, 295, 1995, 97-106.

[26] J. Kohlmeyer, Wood inhabiting marine fungi from Pacific Northwest and California. Nova Hedwigia, 2, $1960.293-343$.

[27] G.C. Hughes, Studies of fungi in oceans and estuaries since 1961. I. Lignicolous, caulicolous and foliicolous species. Oceanography and Marine Biology, An Annual Review, 13, 1975, 69-180.

[28] T.W. Jr. Johnson, The estuarine mycoflora, in G.H. Lauff, (Ed.). Estuaries. Publ. No.83. Am. Assoc. Adv. Sci., Washigton, D.C., 1967, 303-305.

[29] E. J. F. Wood, Marine Microbial Ecology. (London: Chapman and Hall, 1965). 